\title{
Water resources conservation and nitrogen pollution reduction under global food trade and agricultural intensification
}

\author{
Wenfeng Liu ${ }^{\text {a,*}}$, Hong Yang a,b ${ }^{\text {, Yu Liu }}{ }^{\text {c,d }}$, Matti Kummu ${ }^{\text {e }}$, Arjen Y. Hoekstra ${ }^{\text {f,g }}$, Junguo Liu ${ }^{\text {h }}$, Rainer Schulin ${ }^{\text {i }}$ \\ a Eawag, Swiss Federal Institute of Aquatic Science and Technology, Ueberlandstrasse 133, CH-8600 Duebendorf, Switzerland \\ b Department of Environmental Sciences, MGU, University of Basel, Petersplatz 1, CH-4003 Basel, Switzerland \\ c Institutes of Science and Development, Chinese Academy of Sciences, Beijing 100190, China \\ d School of Public Policy and Management, University of Chinese Academy of Sciences, Beijing 100049, China \\ e Water E' Development Research Group, Aalto University, Tietotie 1E, 02150 Espoo, Finland \\ ${ }^{\mathrm{f}}$ Twente Water Centre, University of Twente, Enschede, The Netherlands \\ ${ }^{g}$ Institute of Water Policy, Lee Kuan Yew School of Public Policy, National University of Singapore, Singapore

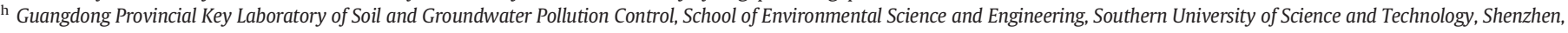 \\ China \\ i ETH Zürich, Institute of Terrestrial Ecosystems, Universitätstr. 16, CH-8092 Zürich, Switzerland
}

\section{H I G H L I G H T S}

- We investigate flows of water resources and nitrogen $(\mathrm{N})$ pollution associated with international food trade.

- A grid-based crop model is combined with the Global Trade Analysis Project model for the investigation.

- Global trade of three major cereal crops conserves water and $\mathrm{N}$ uses and reduces $\mathrm{N}$ losses.

- Agriculture intensification increases crop yields but reduces food-trade related water and $\mathrm{N}$ savings and pollution reduction.

\section{A R T I C L E I N F O}

\section{Article history:}

Received 17 January 2018

Received in revised form 23 March 2018

Accepted 24 March 2018

Available online $\mathrm{xxxx}$

Editor: Jay Gan

\section{Keywords:}

Food trade

Water resources conservation

Nitrogen pollution reduction

Agricultural intensification

PEPIC

GTAP

\footnotetext{
* Corresponding author.

E-mail address: wenfeng.liu@eawag.ch. (W. Liu).
}

GRA PHICAL A B S T R A C T

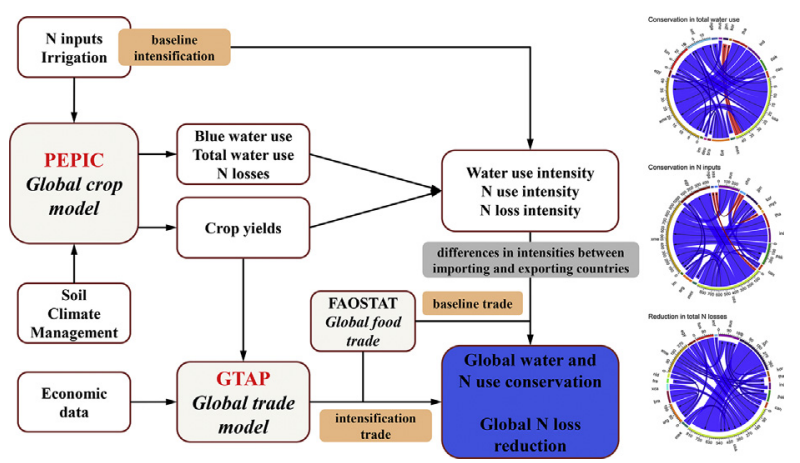

\section{A B S T R A C T}

Global food trade entails virtual flows of agricultural resources and pollution across countries. Here we performed a global-scale assessment of impacts of international food trade on blue water use, total water use, and nitrogen $(\mathrm{N})$ inputs and on $\mathrm{N}$ losses in maize, rice, and wheat production. We simulated baseline conditions for the year 2000 and explored the impacts of an agricultural intensification scenario, in which low-input countries increase $\mathrm{N}$ and irrigation inputs to a greater extent than high-input countries. We combined a crop model with the Global Trade Analysis Project model. Results show that food exports generally occurred from regions with lower water and $\mathrm{N}$ use intensities, defined here as water and $\mathrm{N}$ uses in relation to crop yields, to regions with higher resources use intensities. Globally, food trade thus conserved a large amount of water resources and $\mathrm{N}$ applications, and also substantially reduced $\mathrm{N}$ losses. The trade-related conservation in blue water use reached $85 \mathrm{~km}^{3} \mathrm{y}^{-1}$, accounting for more than half of total blue water use for producing the three crops. Food exported from the USA contributed the largest proportion of global water and $\mathrm{N}$ conservation as well as $\mathrm{N}$ loss reduction, but also led to substantial export-associated $\mathrm{N}$ losses in the country itself. Under the intensification scenario, the converging water and $\mathrm{N}$ use intensities across countries result in a more balanced world; crop trade will generally decrease, and global water resources conservation and $\mathrm{N}$ pollution reduction associated with the trade will reduce accordingly. The 
study provides useful information to understand the implications of agricultural intensification for international crop trade, crop water use and $\mathrm{N}$ pollution patterns in the world.

(c) 2018 Elsevier B.V. All rights reserved.

\section{Introduction}

Global food trade not only redistributes food supply between trading countries but also entails flows of imbedded water resources, resulting so called virtual water flows. Water resources are to a greater or lesser extent bound to the place where they occur, but the possibility to use them for producing export products makes them global (Hoekstra, 2017; Hoekstra and Hung, 2005). It has been estimated that around the year 2000 the volume of virtual water flowing throughout the world as a result of international food trade amounted to one-fifth of total water consumption for agricultural production (Hoekstra and Mekonnen, 2012). With the expansion of international trade, virtual water trade has been increasing during the past few decades (Antonelli et al., 2017; D'Odorico et al., 2014; Kastner et al., 2014). The influence of inter- or intra-national food trade on water resources utilization across trade partners has been intensively studied (Antonelli and Tamea, 2015; Ercin and Hoekstra, 2014; Feng et al., 2014; Porkka et al., 2017; Wang and Zimmerman, 2016; Zhang et al., 2012; Zhao et al., 2015; Zhuo et al., 2016).

In addition to water, other agricultural resources as well as environmental quality are influenced by international food trade. In particular, impacts on nutrients such as nitrogen (N) (Lassaletta et al., 2016; Liu et al., 2016a; Oita et al., 2016; Smil, 1999) and phosphorus (Lun et al., 2018; Nesme et al., 2016), land (Fader et al., 2011), water pollution (O'Bannon et al., 2014), deforestation (DeFries et al., 2010), and fine particulate matter $\left(\mathrm{PM}_{2.5}\right)$ (Zhang et al., 2017) have been studied. For instance, it was estimated that about a quarter of global $\mathrm{N}$ emissions were driven by demand for international trade in 2010 (Oita et al., 2016).

International food trade could serve to conserve global agricultural resources and alleviate environmental degradation if food were to be exported from regions with lower resources use and pollution intensities, where intensities are defined as the ratios of resources use and pollution emissions to crop yields, to regions with higher resources use and pollution intensities. Whereas the impacts of food trade on water conservation have been widely studied (Chapagain et al., 2006; Konar et al., 2016; Oki and Kanae, 2004; Yang et al., 2006), the effects of food trade on conserving other resources and reducing environmental pollution are still largely unclear (Dalin and Rodriguez-Iturbe, 2016). Furthermore, investigations of trade impacts on resources use and pollution have mainly been conducted by considering one metric at a time, e.g. either N (e.g. Oita et al., 2016) or water (e.g. Dalin et al., 2017). For some specific regions, a few studies have attempted to investigate such impacts through considering multiple aspects. For example, Martinez-Melendez and Bennett (2016) explored the impacts of food trade between the USA and Mexico on land, water, and $\mathrm{N}$ fertilizer use, as well as on nitrous oxide $\left(\mathrm{N}_{2} \mathrm{O}\right)$ emissions, and concluded that the trade between the two countries reduced the environmental costs of agriculture. Zhao et al. (2016) included water, chemical oxygen demand (COD), and ammoniacal nitrogen $\left(\mathrm{NH}_{3}-\mathrm{N}\right)$ to explore the burden shifting of water quantity and quality stress from Shanghai, the largest megacity in China, to its domestic trading partners. On a global scale, MacDonald et al. (2015) applied a multi-metric method to investigate the effects of global agricultural trade by considering economic, nutritional, and environmental dimensions of globalization and concluded that multi-metric research on global agricultural trade is important to interpret trade composition and structure. However, their study did not explicitly explore the extent to which agricultural trade can save resources and reduce environmental impacts. There is a lack of literature employing a multi-metric perspective on the beneficial gains of international food trade for resources and environment, not only regarding the past but also for a future of intensification in agriculture. Such an assessment is essential for improving our broader understanding of the impacts of trade on a global scale (MacDonald et al., 2012; Yang et al., 2013).

Here, for the first time, we performed a comprehensive global-scale investigation of trade effects for the three major crops-maize, rice, and wheat-on conserving water resources use and reducing $\mathrm{N}$ emissions to the environment, comparing the baseline situation around the year 2000 to a scenario of agricultural intensification. The three crops accounted for about $55 \%$ of global total virtual water flows of 38 different crops considered in Hoekstra and Hung (2005). A multi-metric perspective of global food trade effects was explored by taking blue water use (BWU), total water use (TWU) and $\mathrm{N}$ inputs $\left(\mathrm{N}_{\text {in }}\right)$, as well as $\mathrm{N}$ losses from agriculture to water $\left(\mathrm{N}_{\mathrm{W}}\right)$ and the total environment $\left(\mathrm{N}_{\mathrm{t}}\right)$ into consideration. BWU refers to the evapotranspiration (ET) derived from irrigation water applied to crop fields, also referred to as blue water consumption. TWU includes BWU and green water use. It refers to total ET, i.e. the sum of ET from irrigation water (blue water) and rainwater (green water). $\mathrm{N}$ emissions from crop production due to $\mathrm{N}$ fertilization were considered here mainly due to their significant impacts on human and ecosystems' health (Liu et al., 2017; Sutton et al., 2013; Zhu et al., 2005). Both water and $\mathrm{N}$ fertilizers are essential for crop growth and they affect agricultural performance in an interactive way (Mueller et al., 2012). Depletion of global water resources, especially blue water, and emissions of $\mathrm{N}$ from fertilization to environment have become critical concerns in many parts of the world (West et al., 2014). Therefore, investigation on the five important aspects relating to tradeoffs of crop production and environmental impacts in both exporting and importing countries can provide useful information to support the integrated management of water, food and environment.

In this study, a physical- and grid-based crop model Environmental Policy Integrated Climate (EPIC/PEPIC) was combined with the Global Trade Analysis Project (GTAP) to conduct the investigation. In addition to the baseline calculations, we also considered an agricultural intensification scenario, in which we assumed increases in $\mathrm{N}$ inputs and irrigated cultivation areas. The purpose of the scenario analysis was to illustrate possible impacts of agricultural intensification, which is advocated for achieving larger crop yields and production enhancement in low-input regions (Mueller et al., 2012), on global water resources conservation and environmental quality. The trends demonstrated in the intensification scenario reflect a general situation under any other agricultural intensification. The study provides useful information for understanding the complex implications of agricultural intensification for international crop trade, crop water use and $\mathrm{N}$ pollution patterns in the world.

\section{Methodology and data description}

In this study, we combined EPIC/PEPIC and GTAP to investigate water and $\mathrm{N}$ use conservation and $\mathrm{N}$ pollution reduction associated with global food trade under the baseline and intensification scenarios. Fig. 1 presents the schematic of the analytical framework used in this study, while our methodology is briefly summarized below with more details in following sub-sections.

We used the EPIC/PEPIC model (Liu et al., 2016b; Williams et al., 1984) to simulate agricultural BWU, TWU and $\mathrm{N}_{\mathrm{in}}$, as well as $\mathrm{N}_{\mathrm{w}}$ and $\mathrm{N}_{\mathrm{t}}$. To investigate the impact of trade on these variables, we first 


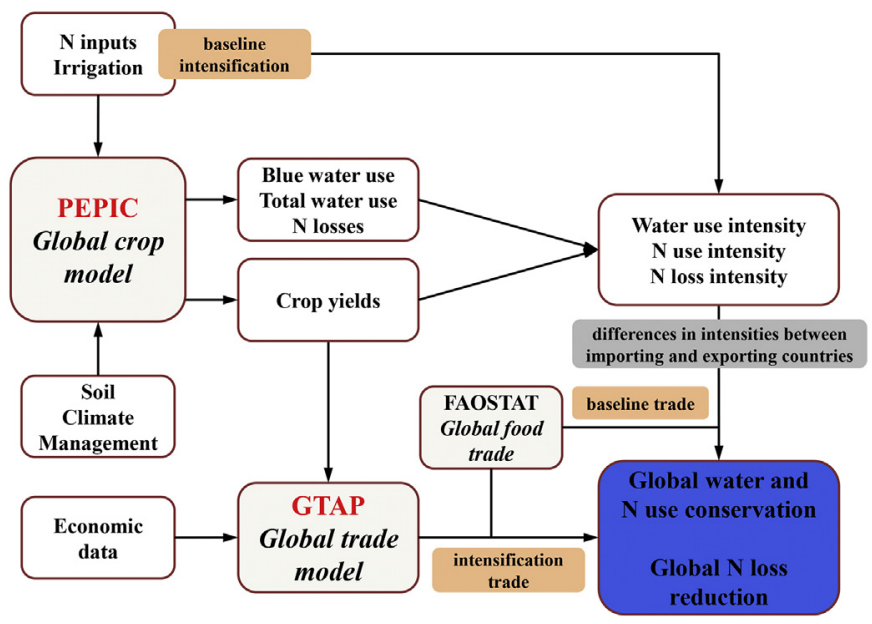

Fig. 1. Schematic of analytical framework used in this study. Two scenarios were considered in the study: baseline and intensification. Global water and $\mathrm{N}$ use conservation is achieved due to the differences in resource use intensities between importing and exporting countries; global $\mathrm{N}$ loss reduction is achieved due to the differences in $\mathrm{N}$ loss intensities between importing and exporting countries.

estimated water use intensity, $\mathrm{N}$ use intensity, and $\mathrm{N}$ loss intensity. Here, water use intensity is calculated as the ratio of water uses to crop yields. $\mathrm{N}$ use intensity measures the ratio of $\mathrm{N}$ uses to crop yields, while $\mathrm{N}$ loss intensity measures the ratio of $\mathrm{N}$ losses to crop yields. Gross virtual resource flows between countries and export-associated $\mathrm{N}$ losses were then calculated by multiplying international food trade volumes with respective water and $\mathrm{N}$ use intensities as well as $\mathrm{N}$ loss intensities in the exporting countries. Finally, water resources and $\mathrm{N}$ application conservation through international food trade were obtained by multiplying exported food volumes with the difference between water and $\mathrm{N}$ use intensities in food importing countries and exporting countries. A similar method was used to estimate $\mathrm{N}$ loss reduction through international food trade.

Under the intensification scenario, the increases in $\mathrm{N}$-input and irrigation area were larger in the regions with low $\mathrm{N}$-input and a high rainfed fraction in the baseline than in regions with high $\mathrm{N}$-input and a high irrigated fraction in the baseline. Hence, global spatial patterns of irrigation and $\mathrm{N}$ inputs are more balanced in the intensification scenario than in the baseline. The GTAP model (Hertel, 1997) was used to estimate bilateral food trade under the intensification scenario, by inputting GTAP with relative changes of simulated yields between intensification and baseline. Then, water resources and $\mathrm{N}$ application conservation and $\mathrm{N}$ loss reduction due to food trade were evaluated for the intensification scenario, similar to the baseline.

\subsection{The EPIC/PEPIC model}

EPIC is a field-scale crop model (Williams, 1995; Williams et al., 1984), which has been widely used to simulate the complex soilwater-climate-management processes related to crop growth (Gassman et al., 2005). It estimates potential biomass increase at a daily step based on an energy-to-biomass approach by multiplying intercepted solar radiation with a crop-specific biomass-energy ratio. Potential biomass increase is then adjusted by a major plant stress factor, including water, temperature, nitrogen, phosphorus, aeration, and salinity. Crop yields are simulated as the product of actual biomass accumulation and a crop-specific harvest index. EPIC provides five options to estimate potential ET, namely Beier-Robertson, Hargreaves, Penman, Penman-Monteith, and Preistly-Taylor. In this study, PenmanMonteith was used as it was found to provide more reliable estimation of global crop-water relations (Liu et al., 2016b).

EPIC adopts the Century model (Parton et al., 1994) to simulate carbon and N dynamics (Izaurralde et al., 2006). N inputs in EPIC include fertilizer and manure application, rainfall $\mathrm{N}$ deposition, and biological $\mathrm{N}$ fixation. $\mathrm{N}$ outputs are $\mathrm{N}$ uptakes by plants, $\mathrm{N}$ emissions to atmosphere through denitrification and volatilization, and $\mathrm{N}$ losses to water bodies through surface runoff, leaching and soil erosion. Denitrification and volatilization are controlled by soil temperature and soil water content, while $\mathrm{N}$ losses to water are mainly determined by $\mathrm{N}$ concentration in water flow. Details about simulation of $\mathrm{N}$ losses can be found in Liu et al. (2016c).

In this study, Python-based EPIC (PEPIC) (Liu et al., 2016b), was used to extend the application of EPIC on a global scale. PEPIC simulated crop yields, crop water consumption, and $\mathrm{N}$ dynamics at a spatial resolution of $30^{\prime}$ for the baseline and intensification scenarios. Previous investigations showed that PEPIC performed well in representing global crop yields and $\mathrm{N}$ losses (Liu et al., 2016b, 2016c). The PEPIC model also contributed to the Global Gridded Crop Model Intercomparison (GGCMI) (Elliott et al., 2015), which is part of the Agricultural Model Intercomparison and Improvement Project (AgMIP) (Rosenzweig et al., 2013). The performance of PEPIC in simulating historical yield variability at the country level compared well with the other 13 global crop models involved in the GGCMI (Müller et al., 2017; Porwollik et al., 2017).

Inputs for the PEPIC model include a digital elevation model (DEM), slope, climate (Weedon et al., 2014), soil (Batjes, 2006), and crop management practices, e.g. irrigation area, fertilizer inputs, and planting and harvesting dates (Sacks et al., 2010). For the baseline, irrigated and rainfed cultivation areas were based on the MIRCA2000 dataset (Portmann et al., 2010). Fertilizer inputs of phosphorus (P) and N (including chemical mineral fertilizer and manure) were obtained from the EarthStat dataset (http://www.earthstat.org) (Mueller et al., 2012; West et al., 2014). Both MIRCA2000 and EarthStat datasets are related to the years around 2000, which are the most up-to-date crop-specific harvest land and fertilizer data available. Irrigation was applied automatically when water deficits for a crop exceeded $10 \%$ of water requirements without water limitation (Folberth et al., 2016). P was applied before planting based on Balkovič et al. (2014), while $\mathrm{N}$ ( $\mathrm{N}_{\text {in-base }}$ based on the EarthStat dataset) was applied three times with equal amount during the whole growth season (Liu et al., 2016c). For the intensification scenario, irrigation was applied in the same way as in the baseline scenario, but converting $10 \%$ of rainfed croplands into irrigated cultivation (Table 1). P was applied automatically by PEPIC without limitation to avoid the P deficiency that would limit plant growth (Folberth et al., 2014). N was applied automatically, triggered by $10 \% \mathrm{~N}$ stress (Liu et al., 2016c). To determine $N$ inputs in the intensification scenario, maximum $\mathrm{N}$ inputs for achieving the potential yields with baseline irrigation coverage $\left(\mathrm{N}_{\text {in-max-base }}\right)$ and with full irrigation coverage $\left(\mathrm{N}_{\text {in-max-full }}\right)$ were first estimated using PEPIC triggered by $10 \% \mathrm{~N}$ stress without $\mathrm{N}$ limitation. The minimum value between $\mathrm{N}_{\text {in-base }}$ and $\mathrm{N}_{\text {in-max-base }}$ was treated as $\mathrm{N}_{\text {in-base-limit }}$ to eliminate baseline $\mathrm{N}$ over-application. The difference of $N_{\text {in-max-full }}$ and $N_{\text {in-base-limit }}$ was calculated as $\Delta N_{\text {in }}$ (Fig. 2). Finally, $N$ inputs in the intensification scenario were estimated by $\mathrm{N}_{\text {in-base-limit }}+$ $0.25 \times \Delta \mathrm{N}_{\text {in }}$ (Table 1). It should be noted that the idea of the designed intensification scenario is to propose a relatively balanced agricultural condition in terms of $\mathrm{N}$ and irrigation inputs. The proposed intensification scenario is therefore an illustration of such idea.

Table 1

Description of the baseline and intensification scenarios in terms of increasing nitrogen inputs and irrigation areas.

\begin{tabular}{llll}
\hline Scenario & $\mathrm{N}$ inputs & Irrigation areas & Rainfed areas \\
\hline baseline & $\mathrm{N}_{\text {in-base }}$ & $\mathrm{A}_{\text {ir }}$ & $\mathrm{A}_{\mathrm{rf}}$ \\
intensification & $\mathrm{N}_{\text {in-base-limit }}+0.25 \times \Delta \mathrm{N}_{\text {in }}$ & $\mathrm{A}_{\mathrm{ir}}+0.10 \times \mathrm{A}_{\mathrm{rf}}$ & $0.9 \times \mathrm{A}_{\mathrm{rf}}$ \\
\hline
\end{tabular}

$\mathrm{N}_{\text {in-base }}$ is actual $\mathrm{N}$ inputs based on the EarthStat dataset; $\mathrm{N}_{\text {in-base-limit }}=\min \left(\mathrm{N}_{\text {in-base}}\right.$, $\mathrm{N}_{\text {in-max-base }}$ ), where $\mathrm{N}_{\text {in-max-base }}$ is maximum $\mathrm{N}$ inputs based on PEPIC simulation with

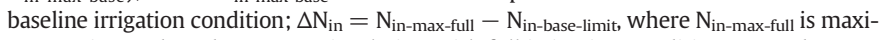
mum $N$ inputs based on PEPIC simulation with full irrigation condition; $A_{\text {ir }}$ and $A_{\mathrm{rf}}$ are baseline irrigation and rainfed cultivation areas based on the MIRCA2000 dataset. 
(a) baseline $\mathrm{N}$ under-application

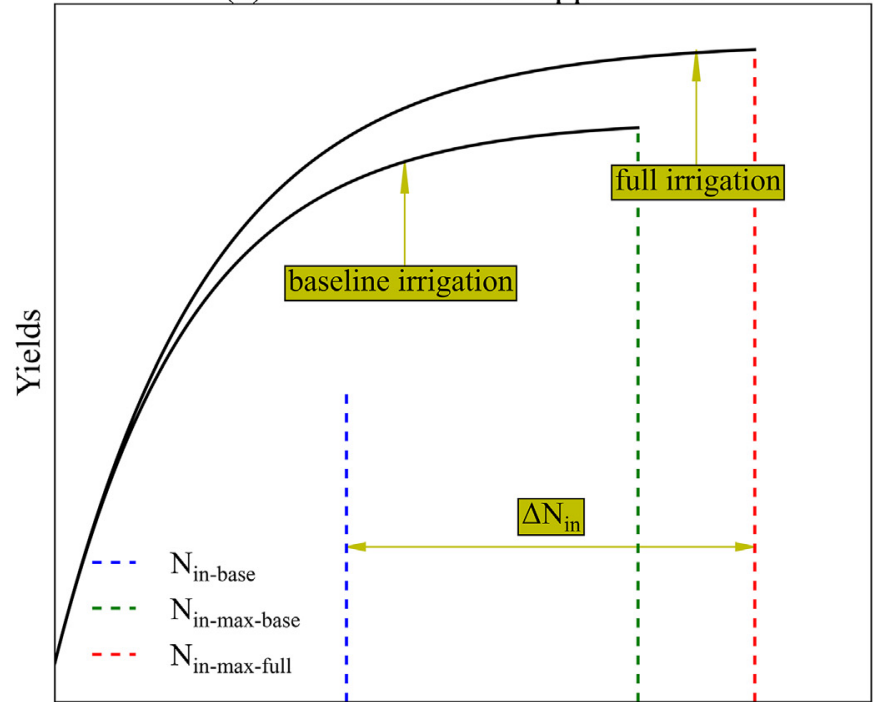

(b) baseline $\mathrm{N}$ over-application

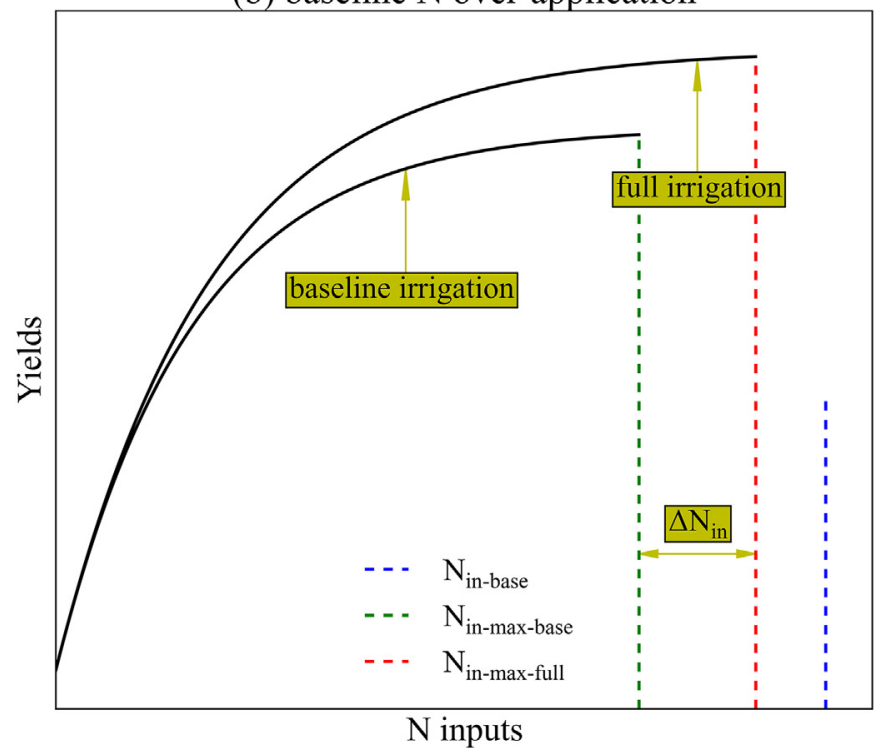

Fig. 2. Conceptual description for obtaining the maximum increases in nitrogen (N) inputs. (a) under condition of baseline $\mathrm{N}$ under-application; (b) under condition of baseline $\mathrm{N}$ over-application; $\mathrm{N}_{\text {in-base }}$ : baseline $\mathrm{N}$ inputs based on EarthStat dataset; $\mathrm{N}_{\text {in-max-base }}$ : maximum $\mathrm{N}$ inputs based on PEPIC simulation with baseline irrigation coverage; $\mathrm{N}_{\text {in-max-full: }}$ maximum $\mathrm{N}$ inputs based on PEPIC simulation with full irrigation coverage (here full irrigation coverage means that all the current cropland areas are treated as irrigated cultivation). $\Delta \mathrm{N}_{\text {in }}=\mathrm{N}_{\text {in-max-full }}-\mathrm{N}_{\text {in-base-limit }}$, where $\mathrm{N}_{\text {in-base-limit }}=\min \left(\mathrm{N}_{\text {in-base }}, \mathrm{N}_{\text {in-max-base }}\right)$.

\subsection{The GTAP model}

The GTAP model is a multi-sector and multi-region general equilibrium global trade model with constant returns to scale and perfect competition, considering capital, land, natural resources, skilled labor, and unskilled labor as production factors (Hertel, 1997). It provides a detailed description of the demand and supply for each sector and each region. The GTAP model has been widely used to investigate the impacts of changes in yields on international trade (Konar et al., 2013; Konar et al., 2016; Liu et al., 2014). In GTAP, yield improvements due to agricultural input intensification, e.g. irrigation expansion and $\mathrm{N}$ fertilizer additions, affect food trade through changing food production and food price. In this study, percentage changes in crop yields of the three crops between the intensification and baseline scenarios simulated by
PEPIC were fed into the GTAP model as a shocking factor. Then trade value (in million US dollars) was estimated for the intensification scenario considering crop yield improvements. Percentage differences in trade value between intensification (here price effects on final trade value were eliminated) and baseline were calculated by GTAP. Exported food volumes (EFV) $\left[\mathrm{t}^{-1}\right]$ for the intensification scenario was obtained by multiplying reported EFV for the baseline with the percentage differences in trade value between the intensification and baseline scenarios.

Here the GTAP v6 database was used for simulation. The GTAP v6 database provides trade value data between trading partners. The GTAP database for the year 2001 was used here because the MIRCA2000 land-use data and the EarthStat fertilizer data under the baseline simulation were mainly related to the period 1998-2002. The average gross bilateral EFV of the three crops between 1998 and 2002 were obtained from FAOSTAT (http://www.fao.org/faostat/en/\#home). Countryspecific food EFV was then aggregated to 96 regions defined in the GTAP v6 database (Tables S1 and S2).

\subsection{Variable descriptions}

The variables used in this study include crop yield ( $\mathrm{Y}$ ) [ $\left.\mathrm{tha}^{-1}\right]$, BWU [mm], TWU [mm], $\mathrm{N}_{\text {in }}\left[\mathrm{kg} \mathrm{N}^{-1}\right], \mathrm{N}_{\mathrm{w}}\left[\mathrm{kg} \mathrm{N}^{-1}\right]$, and $\mathrm{N}_{\mathrm{t}}\left[\mathrm{kg} \mathrm{N} \mathrm{ha}^{-1}\right]$. All these variables are area-weighted averages of irrigated and rainfed simulations. TWU refers to growing season evapotranspiration. BWU is the part of the total growing season evapotranspiration derived from irrigation water. It was calculated based on Liu et al. (2009). $\mathrm{N}_{\mathrm{w}}$ is $\mathrm{N}$ loss with surface runoff, leaching and erosion. $\mathrm{N}_{\mathrm{t}}$ is the sum of $\mathrm{N}_{\mathrm{w}}$ and $\mathrm{N}$ loss to the atmosphere.

In order to assess gross virtual water and $\mathrm{N}$ use export, and $\mathrm{N}$ losses associated with food export, we first calculated water and $\mathrm{N}$ use intensities and $\mathrm{N}$ loss intensities relative to crop yields at the country level aggregated from grid level using area-weighted averages:

$$
\begin{aligned}
& \text { BWUI }=10 * \mathrm{BWU} / \mathrm{Y} \\
& \text { TWUI }=10 * \text { TWU } / Y \\
& \mathrm{~N}_{\text {in }} \mathrm{I}=\mathrm{N}_{\text {in }} / \mathrm{Y} \\
& \mathrm{N}_{\mathrm{W}} \mathrm{I}=\mathrm{N}_{\mathrm{W}} / \mathrm{Y} \\
& \mathrm{N}_{\mathrm{t}} \mathrm{I}=\mathrm{N}_{\mathrm{t}} / \mathrm{Y}
\end{aligned}
$$

where BWUI $\left[\mathrm{m}^{3} \mathrm{t}^{-1}\right]$, TWUI $\left[\mathrm{m}^{3} \mathrm{t}^{-1}\right], \mathrm{N}_{\mathrm{in}} \mathrm{I}\left[\mathrm{kg} \mathrm{N} \mathrm{t}^{-1}\right], \mathrm{N}_{\mathrm{w}} \mathrm{I}\left[\mathrm{kg} \mathrm{N} \mathrm{t}^{-1}\right]$, and $\mathrm{N}_{\mathrm{t}} \mathrm{I}\left[\mathrm{kg} \mathrm{N} \mathrm{t}^{-1}\right]$ are blue water use intensity, total water use intensity, $\mathrm{N}$ use intensity, water $\mathrm{N}$ loss intensity and total $\mathrm{N}$ loss intensity at country level, respectively. The 10 is used for unit transformation. It should be noted that here we assumed that for a given exporting country and for a given crop species, crop export occurs evenly across the country's regions of production of that crop species, without considering crop producing regions dedicated for domestic consumption or for exporting. This assumption was needed to be done mainly due to limited data availability. Then, gross virtual BWU, TWU, and $\mathrm{N}_{\text {in }}$ export, as well as $\mathrm{N}_{\mathrm{w}}$ and $\mathrm{N}_{\mathrm{t}}$ associated with export were obtained by multiplying EFV with the corresponding intensities:

$$
\begin{aligned}
& \operatorname{BWUExp}_{\mathrm{e}, \mathrm{i}}=\operatorname{BWUI}_{\mathrm{e}} * \operatorname{EFV}_{\mathrm{e}, \mathrm{i}} \\
& \operatorname{TWUExp}_{\mathrm{e}, \mathrm{i}}=\operatorname{TWUI}_{\mathrm{e}} * \operatorname{EFV}_{\mathrm{e}, \mathrm{i}} \\
& \mathrm{N}_{\mathrm{in}} \operatorname{Exp}_{\mathrm{e}, \mathrm{i}}=\mathrm{N}_{\mathrm{in}} \mathrm{I}_{\mathrm{e}} * \operatorname{EFV}_{\mathrm{e}, \mathrm{i}} \\
& \mathrm{N}_{\mathrm{w}} \operatorname{Exp}_{\mathrm{e}, \mathrm{i}}=\mathrm{N}_{\mathrm{w}} \mathrm{I}_{\mathrm{e}} * \operatorname{EFV}_{\mathrm{e}, \mathrm{i}} \\
& \mathrm{N}_{\mathrm{t}} \operatorname{Exp}_{\mathrm{e}, \mathrm{i}}=\mathrm{N}_{\mathrm{t}} \mathrm{I}_{\mathrm{e}} * \operatorname{EFV}_{\mathrm{e}, \mathrm{i}}
\end{aligned}
$$


Table 2

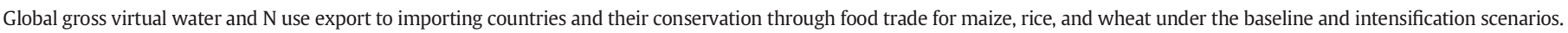
BWU: blue water use; TWU: total water use; $\mathrm{N}_{\text {in }}$ : nitrogen inputs.

\begin{tabular}{|c|c|c|c|c|c|c|c|c|c|}
\hline \multirow[t]{2}{*}{ Scenario } & \multirow[t]{2}{*}{ Variable } & \multicolumn{4}{|c|}{ Gross virtual water and $\mathrm{N}$ use export to importing countries } & \multicolumn{4}{|c|}{ Water and $\mathrm{N}$ use conservation through food trade } \\
\hline & & Maize & Rice & Wheat & Sum & Maize & Rice & Wheat & Sum \\
\hline \multirow[t]{3}{*}{ baseline } & BWU $\left(\mathrm{km}^{3} \mathrm{y}^{-1}\right)$ & 4.2 & 6.3 & 3.3 & 13.8 & 24.9 & 36.7 & 23.4 & 85.0 \\
\hline & TWU $\left(\mathrm{km}^{3} \mathrm{y}^{-1}\right)$ & 53.0 & 26.8 & 141.2 & 221.0 & 41.7 & 42.1 & 21.0 & 104.8 \\
\hline & $\mathrm{N}_{\text {in }}\left(\mathrm{Gg} \mathrm{N} \mathrm{y}^{-1}\right)$ & 1623 & 748 & 3251 & 5621 & 515 & 453 & 1366 & 2333 \\
\hline \multirow[t]{3}{*}{ intensification } & BWU $\left(\mathrm{km}^{3} \mathrm{y}^{-1}\right)$ & 4.1 & 2.4 & 6.2 & 12.6 & 14.7 & 29.1 & 30.4 & 74.3 \\
\hline & TWU $\left(\mathrm{km}^{3} \mathrm{y}^{-1}\right)$ & 40.9 & 11.8 & 115.0 & 167.7 & 11.8 & 27.8 & 27.8 & 67.5 \\
\hline & $\mathrm{N}_{\mathrm{in}}\left(\mathrm{Gg} \mathrm{N} \mathrm{y}^{-1}\right)$ & 1642 & 320 & 4646 & 6608 & 332 & -54 & 593 & 871 \\
\hline
\end{tabular}

where BWUExp $\mathrm{E}_{\mathrm{e}, \mathrm{i}}\left[\mathrm{m}^{3}\right]$, TWUExp $_{\mathrm{e}, \mathrm{i}}\left[\mathrm{m}^{3}\right], \mathrm{N}_{\mathrm{in}} \operatorname{Exp}_{\mathrm{e}, \mathrm{i}}[\mathrm{kg} \mathrm{N}]$ are gross virtual resource export from exporting country, e, to importing country, i, for BWU, TWU, and $\mathrm{N}_{\mathrm{in}}$, respectively; $\mathrm{N}_{\mathrm{w}} \operatorname{Exp}_{\mathrm{e}, \mathrm{i}}[\mathrm{kg} \mathrm{N}]$ and $\mathrm{N}_{\mathrm{t}} \operatorname{Exp}_{\mathrm{e}, \mathrm{i}}[\mathrm{kg} \mathrm{N}]$ are export-associated $\mathrm{N}_{\mathrm{w}}$ and $\mathrm{N}_{\mathrm{t}}$. On the basis of the intensity differences between importing and exporting countries, water and $\mathrm{N}$ use conservation and $\mathrm{N}$ pollution reduction through food trade were calculated using the following equations:

$$
\begin{aligned}
& \text { BWUCon }_{\mathrm{e}, \mathrm{i}}=\left(\mathrm{BWUI}_{\mathrm{i}}-\mathrm{BWUI}_{\mathrm{e}}\right) * \mathrm{EFV}_{\mathrm{e}, \mathrm{i}} \\
& \text { TWUCon }_{\mathrm{e}, \mathrm{i}}=\left(\mathrm{TWUI}_{\mathrm{i}}-\mathrm{TWUI}_{\mathrm{e}}\right) * \mathrm{EFV}_{\mathrm{e}, \mathrm{i}} \\
& \mathrm{N}_{\mathrm{in}} \operatorname{Con}_{\mathrm{e}, \mathrm{i}}=\left(\mathrm{N}_{\mathrm{in}} \mathrm{I}_{\mathrm{i}}-\mathrm{N}_{\mathrm{in}} \mathrm{I}_{\mathrm{e}}\right) * \mathrm{EFV}_{\mathrm{e}, \mathrm{i}} \\
& \mathrm{N}_{\mathrm{W}} \operatorname{Red}_{\mathrm{e}, \mathrm{i}}=\left(\mathrm{N}_{\mathrm{w}} \mathrm{I}_{\mathrm{i}}-\mathrm{N}_{\mathrm{W}} \mathrm{I}_{\mathrm{e}}\right) * \mathrm{EFV}_{\mathrm{e}, \mathrm{i}} \\
& \mathrm{N}_{\mathrm{t}} \operatorname{Red}_{\mathrm{e}, \mathrm{i}}=\left(\mathrm{N}_{\mathrm{t}} \mathrm{I}_{\mathrm{i}}-\mathrm{N}_{\mathrm{t}} \mathrm{I}_{\mathrm{e}}\right) * \mathrm{EFV}_{\mathrm{e}, \mathrm{i}}
\end{aligned}
$$

where BWUCon $_{e, i}\left[\mathrm{~m}^{3}\right]$, TWUCon $_{e, \mathrm{i}}\left[\mathrm{m}^{3}\right], \mathrm{N}_{\mathrm{in}} \operatorname{Con}_{\mathrm{e}, \mathrm{i}}[\mathrm{kg} \mathrm{N}], \mathrm{N}_{\mathrm{w}} \operatorname{Red}_{\mathrm{e}, \mathrm{i}}$ [ $\mathrm{kg} \mathrm{N}]$, and $\mathrm{N}_{\mathrm{t}} \operatorname{Red}_{\mathrm{e}, \mathrm{i}}[\mathrm{kg} \mathrm{N}]$ are BWU conservation, TWU conservation, $\mathrm{N}_{\text {in }}$ conservation, $\mathrm{N}_{\mathrm{w}}$ reduction, and $\mathrm{N}_{\mathrm{t}}$ reduction through food trade from exporting country, e, to importing country, i, respectively. A positive value of the five variables means water and $\mathrm{N}$ use conservation or $\mathrm{N}$ pollution reduction, while a negative value means increase in water and $\mathrm{N}$ use consumption or $\mathrm{N}$ pollution. Finally, global water and $\mathrm{N}$ use conservation through food trade was calculated as the sum of water and $\mathrm{N}$ use conservation resulting from the entire trade and global $\mathrm{N}$ loss reduction as the sum of $\mathrm{N}$ losses avoided due to international trade of the respective crop, compared to the hypothetical situation with no trade, in which the import of crops would be replaced by equivalent amounts of additional crop production in the importing countries.

\subsection{Presenting the trade patterns}

In order to present the patterns of flows of resources and $\mathrm{N}$ pollution, as well as resource conservation and pollution reduction between exporting and importing countries associated with food trade, the "circlize" package within the R coding environment (Gu, 2014) was used to draw circular plots. In the circular plots, all trading countries, both exporting and importing countries, are included in a circle and each country is represented by a beam. In this study, two kinds of circular plots were designed: one for resources and pollution flows and the other for resource conservation and pollution reduction. In the plots for resources and pollution flows, the length of each beam indicates the total amount of exporting and importing for one country. Links with arrows among different beams show the direction of resources and pollution flows and are distinguished by different colors. In the plots for resource conservation and pollution reduction, the length of each beam indicates the total amount of conserved water or $\mathrm{N}$ uses, as well as reduced $\mathrm{N}$ pollution. Links in the second kind of plots are only presented by blue and red colors. Blue color shows positive effect of food trade, i.e. food trade from regions with lower water and $\mathrm{N}$ use intensities as well as $\mathrm{N}$ loss intensities to regions with higher intensities; while red color shows negative effect of food trade. It should be noted that arrows were designed to point to importing countries for BWU export, TWU export, and $\mathrm{N}_{\text {in }}$ export, as well as their related conservation; however, they were set to point to exporting countries for exportassociated $\mathrm{N}_{\mathrm{w}}$ and $\mathrm{N}_{\mathrm{t}}$, because these export-associated $\mathrm{N}_{\mathrm{w}}$ and $\mathrm{N}_{\mathrm{t}}$ were retained in the exporting countries and can be regarded as virtual flows of $\mathrm{N}$ losses from importing countries to exporting countries.

\section{Results}

\subsection{Virtual water and $N$ use export and global conservation through food trade}

International trade in the three crops in the year 2000 involved a total gross virtual water and $\mathrm{N}$ use export of $14 \mathrm{~km}^{3} \mathrm{y}^{-1}$, $221 \mathrm{~km}^{3} \mathrm{y}^{-1}$, and $5621 \mathrm{Gg} \mathrm{N} \mathrm{y}^{-1}\left(\mathrm{Gg}=10^{9} \mathrm{~g}\right)$ for BWU, TWU, and $\mathrm{N}_{\mathrm{in}}$, respectively (Table 2), accounting for $8 \%, 12 \%$, and $10 \%$, respectively, of the total consumption of these resources (Table 3). Rice contributed the largest percentage of gross virtual BWU export (46\%), while wheat contributed the largest percentages of gross virtual TWU export (64\%) and gross virtual $\mathrm{N}_{\mathrm{in}}$ export (58\%). The USA contributed most to gross virtual water and $\mathrm{N}$ use export, accounting for $40 \%, 30 \%$, and $34 \%$ of

\begin{tabular}{|c|c|c|c|c|c|}
\hline Scenario & Variable & Maize & Rice & Wheat & Sum \\
\hline \multirow[t]{6}{*}{ baseline } & BWU $\left(\mathrm{km}^{3} \mathrm{y}^{-1}\right)$ & 57.1 & 45.8 & 63.9 & 166.8 \\
\hline & TWU $\left(\mathrm{km}^{3} \mathrm{y}^{-1}\right)$ & 617.1 & 545.9 & 689.4 & 1852.4 \\
\hline & $\mathrm{N}_{\mathrm{in}}\left(\mathrm{Gg} \mathrm{N} \mathrm{y}^{-1}\right)$ & $17,867.8$ & $20,493.7$ & $20,919.4$ & $59,280.8$ \\
\hline & $\mathrm{N}_{\mathrm{w}}\left(\mathrm{Gg} \mathrm{N} \mathrm{y}^{-1}\right)$ & 6802.8 & $13,653.1$ & 8603.1 & $29,058.9$ \\
\hline & $\mathrm{N}_{\mathrm{t}}\left(\mathrm{Gg} \mathrm{N} \mathrm{y}^{-1}\right)$ & $12,454.6$ & $17,285.7$ & $14,288.4$ & $44,028.7$ \\
\hline & Production $\left(\operatorname{Tg~}^{-1}\right)$ & 781.6 & 684.2 & 518.8 & 1984.6 \\
\hline \multirow[t]{6}{*}{ intensification } & BWU $\left(\mathrm{km}^{3} \mathrm{y}^{-1}\right)$ & 69.0 & 46.6 & 78.6 & 194.2 \\
\hline & TWU $\left(\mathrm{km}^{3} \mathrm{y}^{-1}\right)$ & 629.7 & 546.8 & 704.9 & 1881.5 \\
\hline & $\mathrm{N}_{\mathrm{in}}\left(\mathrm{Gg} \mathrm{N} \mathrm{y}^{-1}\right)$ & $23,062.7$ & $21,138.9$ & $25,880.3$ & $70,081.8$ \\
\hline & $\mathrm{N}_{\mathrm{w}}\left(\mathrm{Gg} \mathrm{N} \mathrm{y}^{-1}\right)$ & 8323.8 & $13,504.3$ & 6220.0 & $28,048.1$ \\
\hline & $\mathrm{N}_{\mathrm{t}}\left(\mathrm{Gg} \mathrm{N} \mathrm{y}^{-1}\right)$ & $15,467.9$ & $17,719.6$ & $13,781.9$ & $46,969.4$ \\
\hline & Production $\left(\operatorname{Tg}^{-1}\right)$ & 949.6 & 764.0 & 727.1 & 2440.8 \\
\hline
\end{tabular}
global gross virtual export of BWU, TWU, and $\mathrm{N}_{\mathrm{in}}$, respectively (Fig. 3).

Table 3

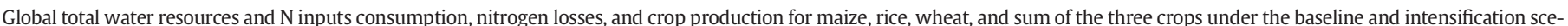
narios. BWU: blue water use; TWU: total water use; $\mathrm{N}_{\mathrm{in}}$ : nitrogen inputs; $\mathrm{N}_{\mathrm{w}}$ : nitrogen losses to water; $\mathrm{N}_{\mathrm{t}}$ : nitrogen losses to the total environment; production: crop production. 
(a) BWU export

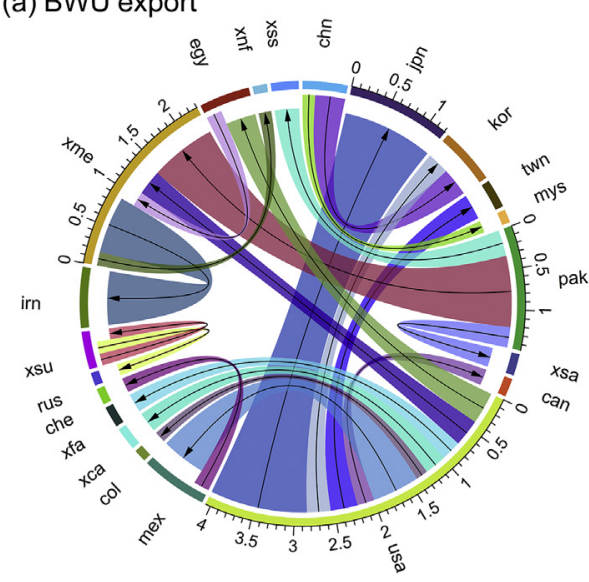

(c) TWU export

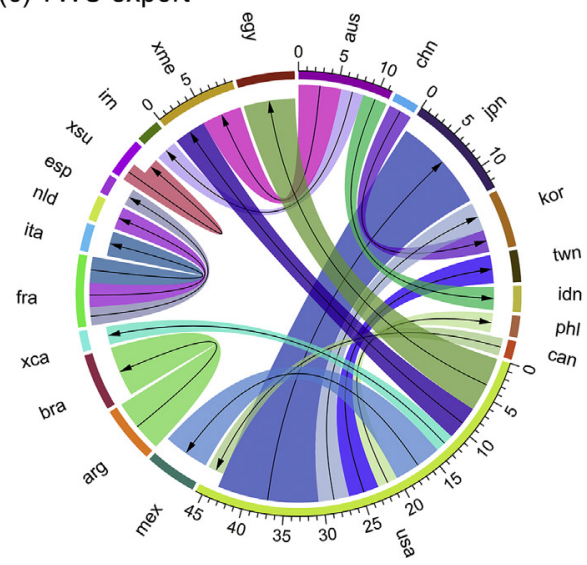

(e) $\mathrm{N}_{\text {in }}$ export

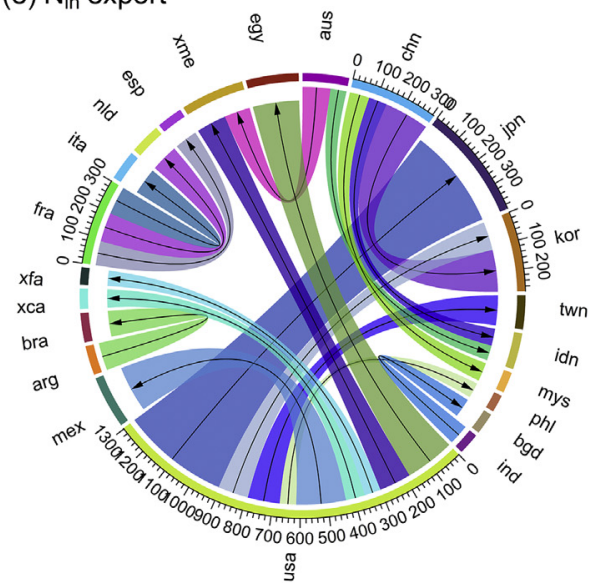

(b) BWU conservation

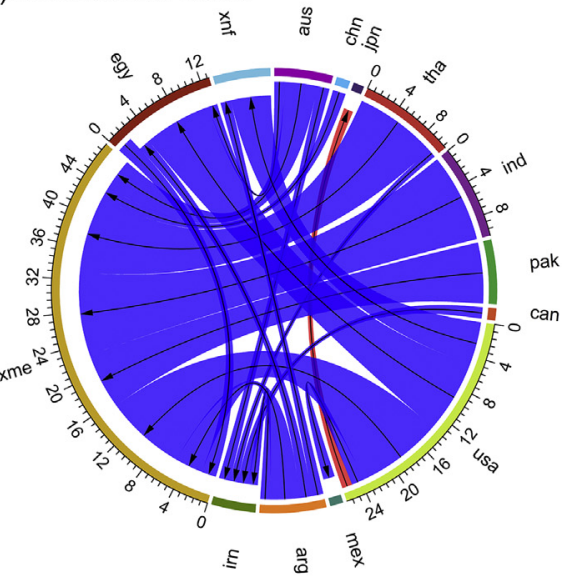

(d) TWU conservation

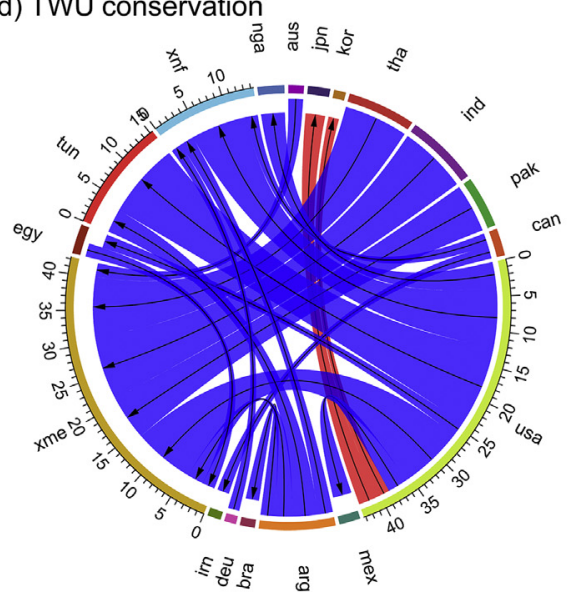

(f) $\mathrm{N}_{\text {in }}$ conservation

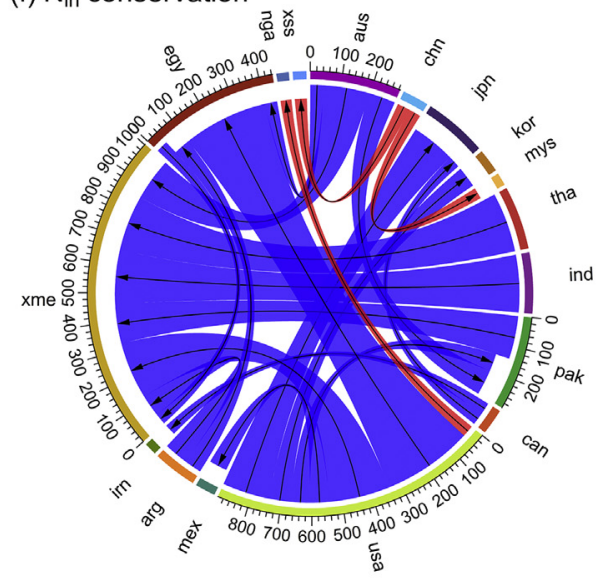

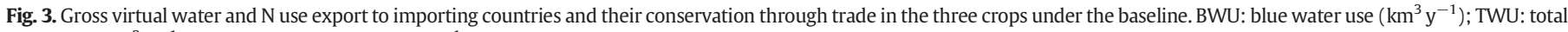

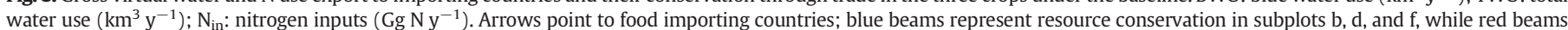

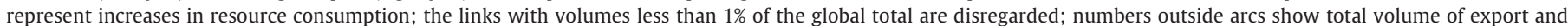

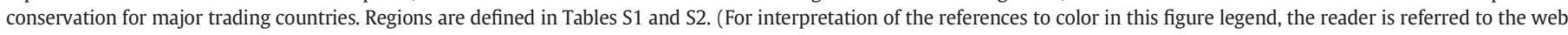
version of this article.)

Because the USA was the major crop exporter for maize and wheat (Fig. S1), the gross virtual export of BWU, TWU, and $\mathrm{N}_{\text {in }}$ from the USA was also the biggest for these two crops (Figs. S2-S4). As for rice, Pakistan exported the largest virtual BWU, while Thailand exported the largest virtual TWU and China exported the largest virtual $\mathrm{N}_{\text {in }}$. Regarding specific trade links, food exported from the USA to Japan was responsible for the largest bilateral virtual flow of BWU, TWU and $\mathrm{N}_{\text {in }}$ (Fig. 3).
We further found that these virtual water and $\mathrm{N}$ use exports generally occurred from regions with lower water and $\mathrm{N}$ use intensities to regions with higher intensities as most links were marked in blue color, while only a few links flowed in the opposite direction (Figs. 3 and S2-S4). It implies that most trade links did conserve global water resources and $\mathrm{N}$ applications. Global water and $\mathrm{N}$ use conservation through trade of the three crops summed up to $85 \mathrm{~km}^{3} \mathrm{y}^{-1}$, $105 \mathrm{~km}^{3} \mathrm{y}^{-1}$, and $2333 \mathrm{Gg} \mathrm{N} \mathrm{y}^{-1}$ for BWU, TWU, and $\mathrm{N}_{\mathrm{in}}$, respectively 
(Table 2). The water conservation was particularly high for BWU. Total global BWU conserved through food trade was six times the total gross virtual export of BWU and accounted for $51 \%$ of the global BWU consumption for the three crops (Table 3). This means that the importing countries on average used much more blue water to produce a unit of these crops than the exporting countries. Also, global TWU and $\mathrm{N}_{\text {in }}$ conservation through food trade reached half of their total gross virtual exports. Global $\mathrm{N}_{\text {in }}$ conservation through food trade was almost equivalent to the total $\mathrm{N}_{\text {in }}$ consumption in Africa and Oceania for producing the three crops. Rice trade conserved most BWU (43\%) and TWU (40\%), while wheat trade conserved most $\mathrm{N}_{\text {in }}$ (59\%). Crop export, mainly from the USA, India, Thailand, and Pakistan, to the Middle East presented the highest potential for conserving global water and $\mathrm{N}$ uses (Fig. 3). The largest fractions of the potential for conservation are the crop export from the USA. However, exporting from the USA to Japan led to losses in water resources.

\subsection{Global reduction in nitrogen pollution through food trade and export- associated nitrogen losses}

Similar to water and $\mathrm{N}$ use conservation, global food trade reduced agricultural $\mathrm{N}$ losses in most bilateral trading links, with only a few links increasing $\mathrm{N}$ losses (Figs. 4 and S5-S7). This means that most exporting countries produced the three crops wasting less $\mathrm{N}$ fertilizer than the importing countries. The total $\mathrm{N}$ losses reduced through food trade were $1924 \mathrm{Gg} \mathrm{N} \mathrm{y}^{-1}$ for $\mathrm{N}_{\mathrm{w}}$ and $2211 \mathrm{Gg} \mathrm{N} \mathrm{y}^{-1}$ for $\mathrm{N}_{\mathrm{t}}$ for all three crops together (Table 4). The main contribution came from international wheat trade. The USA, Australia, and Canada were the top three contributors, together accounting for $80 \%$ and $75 \%$ of total $\mathrm{N}_{\mathrm{w}}$ and $\mathrm{N}_{\mathrm{t}}$ reduction, respectively. The USA contributed the largest $\mathrm{N}_{\mathrm{w}}$ and $\mathrm{N}_{\mathrm{t}}$ reduction with maize and wheat trade, while Thailand reduced the most $\mathrm{N}$ losses with rice trade (Figs. S5-S7). Trade from the USA to Japan led to the largest $\mathrm{N}$ loss reduction associated with a single bilateral trade flow. Rice exported from China mainly resulted in increases in $\mathrm{N}$ losses (Fig. S6).

The simulation results indicate that global food trade conserved water and $\mathrm{N}$ uses and reduced environmental pollution from $\mathrm{N}$ losses in terms of global totals, but the exported crops were still associated with substantial $\mathrm{N}$ losses to the environment in the exporting countries. This part of $\mathrm{N}$ losses was environmental burden shifts from food importing countries to food exporting countries. Total export-associated $\mathrm{N}$ losses related to the three crops reached $1914 \mathrm{Gg} \mathrm{N} \mathrm{y}^{-1}$ and $3681 \mathrm{Gg} \mathrm{N} \mathrm{y}^{-1}$ for $\mathrm{N}_{\mathrm{w}}$ and $\mathrm{N}_{\mathrm{t}}$, respectively (Table 4), accounting for about $7 \%$ and $8 \%$ of the respective total $\mathrm{N}$ losses for the production of the three crops (Table 3 ). Wheat alone accounted for more than half of the global $\mathrm{N}_{\mathrm{w}}$ and $\mathrm{N}_{\mathrm{t}}$ losses associated with the production of the three crops for export, with respective fractions of $54 \%$ and $59 \%$. The USA, France, and China were the major emitters of $\mathrm{N}$ losses associated with food export, together emitting more than half of the $\mathrm{N}_{\mathrm{w}}$ and $\mathrm{N}_{\mathrm{t}}$ on their territories. In particular, the USA alone accounted for about one-third of exportassociated $\mathrm{N}$ losses.

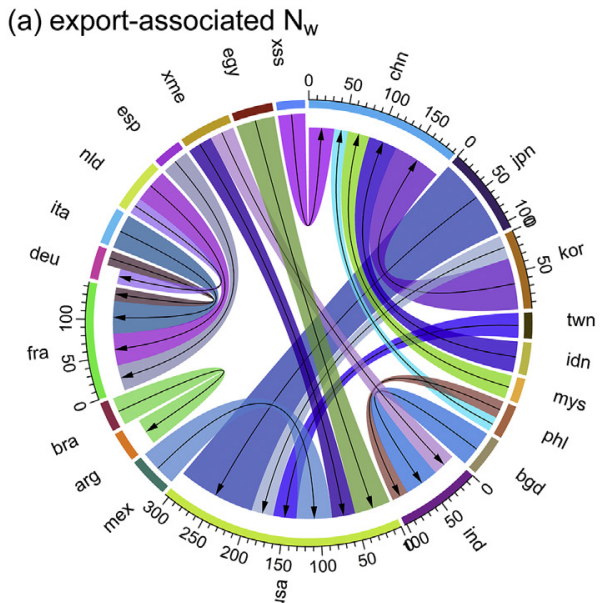

(c) export-associated $\mathrm{N}_{4}$

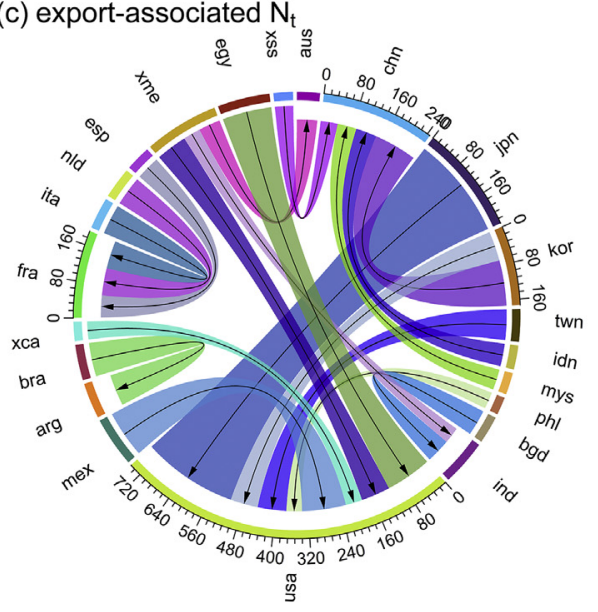

(b) $\mathrm{N}_{\mathrm{w}}$ reduction

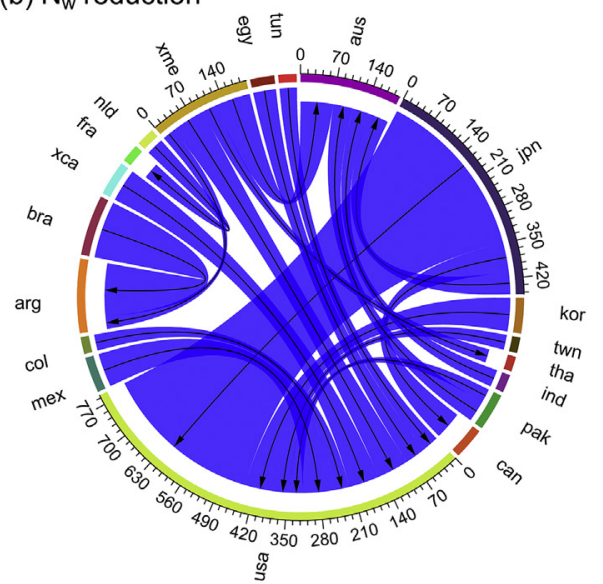

(d) $\mathrm{N}_{\mathrm{t}}$ reduction

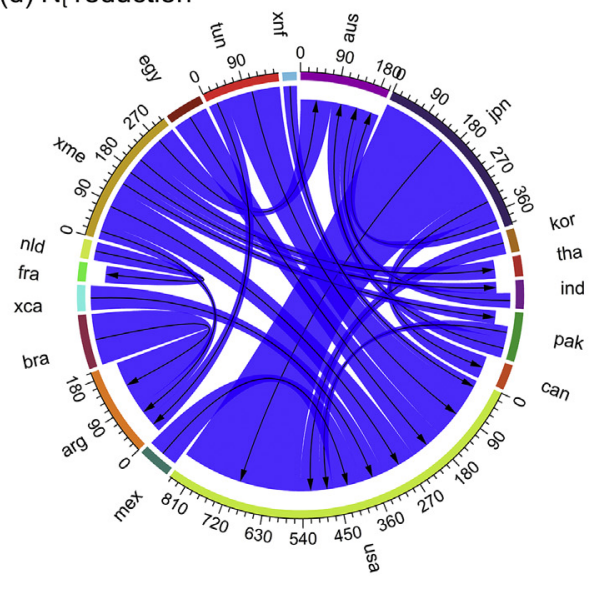

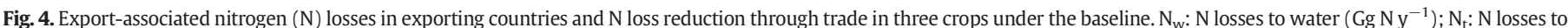

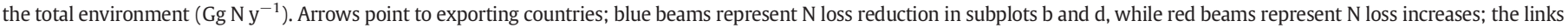

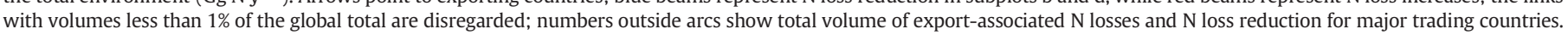
Regions are defined in Tables S1 and S2. (For interpretation of the references to color in this figure legend, the reader is referred to the web version of this article.) 
Table 4

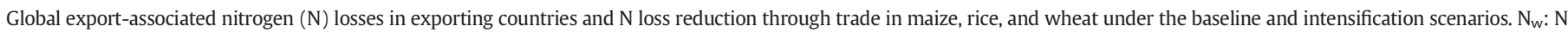
losses to water; $\mathrm{N}_{\mathrm{t}}$ : $\mathrm{N}$ losses to the total environment.

\begin{tabular}{|c|c|c|c|c|c|c|c|c|c|}
\hline \multirow[t]{2}{*}{ Scenario } & \multirow[t]{2}{*}{ Variable } & \multicolumn{4}{|c|}{ Export-associated $\mathrm{N}$ losses in exporting countries } & \multicolumn{4}{|c|}{$\mathrm{N}$ loss reduction through food trade } \\
\hline & & Maize & Rice & Wheat & Sum & Maize & Rice & Wheat & Sum \\
\hline \multirow[t]{2}{*}{ baseline } & $\mathrm{N}_{\mathrm{w}}\left(\mathrm{Gg} \mathrm{N} \mathrm{y}^{-1}\right)$ & 534 & 344 & 1036 & 1914 & 638 & 64.8 & 1221 & 1924 \\
\hline & $\mathrm{N}_{\mathrm{t}}\left(\mathrm{Gg} \mathrm{N} \mathrm{y}^{-1}\right)$ & 1026 & 499 & 2156 & 3681 & 826 & 125 & 1260 & 2211 \\
\hline \multirow[t]{2}{*}{ intensification } & $\mathrm{N}_{\mathrm{w}}\left(\mathrm{Gg} \mathrm{Ny}^{-1}\right)$ & 559 & 141 & 779 & 1479 & 431 & 0.2 & 983 & 1415 \\
\hline & $\mathrm{N}_{\mathrm{t}}\left(\mathrm{Gg} \mathrm{N} \mathrm{y}^{-1}\right)$ & 1000 & 216 & 2080 & 3297 & 486 & 28.0 & 991 & 1505 \\
\hline
\end{tabular}

\subsection{Impacts of agricultural intensification}

Based on the PEPIC and GTAP simulations, agricultural intensification according to the intensification scenario would increase global crop production (Table 3 ) and decrease trade volumes in most trade links (Fig. S1), especially for maize and rice, due to the relatively large increases in crop yields in importing countries with low-input crop production. But it would also largely increase maize export in Argentina and wheat export in Australia, mainly because of their significant yield increases under the intensification scenario and their important roles in exporting the two crops in the world. Consequently, global gross virtual water export and export-associated $\mathrm{N}$ losses would generally decrease in the intensification scenario compared to the baseline scenario (Tables 2 and 4, Figs. S8 and S9). While the flows of virtual $\mathrm{N}_{\text {in }}$ would generally increase, due to increases in $\mathrm{N}$ inputs to soils to be more significant than the decreases in food trade. The exceptions are that export-associated $\mathrm{N}_{\mathrm{w}}$ would slightly increase for maize, that $\mathrm{N}_{\text {in }}$ would largely decrease for rice, and that BWU would increase and $\mathrm{N}_{\text {in }}$ decrease for wheat. Agricultural intensification would also reduce export-associated $\mathrm{N}$ losses in some food exporting countries under the intensification scenario, e.g. China and India (Fig. S9).

Global water and $\mathrm{N}$ use conservation and $\mathrm{N}$ loss reduction through food trade could largely decline under the intensification scenario relative to the baseline, except BWU and TWU conservation would increase for wheat (Tables 2 and 4). In particular, total $\mathrm{N}$ use conservation of the three crops would decrease from $2333 \mathrm{Gg} \mathrm{N} \mathrm{y}^{-1}$ in the baseline to $871 \mathrm{Gg} \mathrm{N} \mathrm{y}^{-1}$ in the intensification scenario. Conservation in $\mathrm{N}$ uses for rice would even become negative, indicating that global rice trade would lead to increased consumption of $\mathrm{N}$ inputs under the intensification scenario. This is mainly due to substantial decreases in $\mathrm{N}$ use conservation through food exported to the Middle East, where the major rice producer Iraq avoided $\mathrm{N}$ over-application and therefore $\mathrm{N}$ use intensity was reduced for the whole Middle East. The declines in the contributions to water and $\mathrm{N}$ use conservation and reduction in $\mathrm{N}$ losses were particularly large for the USA (Figs. S8 and S9). For example, conservation in TWU through trade in the three crops drops from $40 \mathrm{~km}^{3} \mathrm{y}^{-1}$ in the baseline to only $8 \mathrm{~km}^{3} \mathrm{y}^{-1}$ in the intensification scenario in the USA. The major contributors of water and $\mathrm{N}$ use conservation and reduction in $\mathrm{N}$ losses through global food trade would also change for each crop (Figs. S10-S15).

\section{Discussion}

Using the GTAP model in combination with PEPIC, the study reveals that global food trade generates savings of water and fertilizer and reduces the $\mathrm{N}$ pollution caused by agricultural production at the global level. The saved resources and reduced pollution are derived from the differences in resource use intensities and pollution emission intensities between importing and exporting countries. Therefore, they are real beneficial gains for resources and environment in a global perspective. Furthermore, many food importing countries also benefit from food trade by reducing local resource consumption and avoiding environmental degradation. However, these gains come at the expense of water resources and environment in major exporting countries, as they consumed extra resources and retained more pollution to produce food for exporting. The study highlights the challenges in balancing food supply in importing countries with conservation of water and nutrient resources and environmental quality in exporting countries. This study is particularly important, as it combines biophysical with economic modeling in the analysis of the complex relationships between water resources, crop production, environmental impacts, and international food trade. It is the first that is explicitly addressing the effects of international food trade on resource use efficiency and environmental impacts on a global scale from both, import and export, perspectives.

Previous studies found that global food trade conserves TWU and BWU for crop production (Chapagain et al., 2006; Konar et al., 2013; Oki and Kanae, 2004), which is consistent with this study. Particularly, we found that a large amount of BWU was conserved through food trade globally, reaching half of the total BWU consumption for producing the three crops. Further, to our best knowledge, this study for the first time demonstrates that global food trade conserved $\mathrm{N}$ uses and reduced $\mathrm{N}$ losses. The reduction in $\mathrm{N}$ losses is particularly important for human and ecosystem health due to severe $\mathrm{N}$ pollution globally (Sutton et al., 2013). This assessment also largely improves our understanding of the benefits of global food trade in terms of resource conservation and pollution reduction when food trade flows from regions with lower resource use and pollution emission intensities to regions with higher intensities.

However, water and $\mathrm{N}$ use conservation and $\mathrm{N}$ loss reduction associated with global food trade were achieved at the expense of additional water and $\mathrm{N}$ consumption and extra $\mathrm{N}$ losses to producing exporting food in the exporting countries. While, as found in this study, global food trade conserved substantial BWU, virtual water export has placed significant pressure on blue water sustainability in many exporting countries, particularly groundwater depletion induced by international food export (Dalin et al., 2017). For instance, about 9\% of Japan's domestic cereal supply relied on water resources from overexploited aquifers in the USA (Marston et al., 2015). Continuous depletion of blue water resources, associated with an increasing burden of environmental degradation, is challenging virtual water trade (Zhao et al., 2016). From this point of view, reducing the virtual water export and pollution associated with food trade in the USA would alleviate the pressure on its water resources and environment. This could partially explain why there are fewer countries exporting food, as many previous exporters' resource carrying capacities can no longer sustain production for exporting in the context of population growth and social developments (Porkka et al., 2013).

Our estimations of virtual water trade are comparable with previous studies. For example, Liu et al. (2009) concluded that around 6\% of virtual water trade originated from BWU in 2000, consistent with our estimation. The total virtual TWU export of the three crops in this study (221 $\mathrm{km}^{3} \mathrm{y}^{-1}$ under the baseline) is quite close to the estimate of Hanasaki et al. (2010) (213 $\mathrm{km}^{3} \mathrm{y}^{-1}$ in 2000). Also the crop-specific comparison matches very well, i.e. $56,35,122 \mathrm{~km}^{3} \mathrm{y}^{-1}$ for maize, rice, and wheat in Hanasaki et al. (2010) vs. 53, 27, $141 \mathrm{~km}^{3} \mathrm{y}^{-1}$, respectively, in this study. However, due to a lack of crop-specific data on virtual $\mathrm{N}$ use export and export-associated $\mathrm{N}$ losses, we could not compare our estimations of these variables with other studies. This calls for more integrated assessments of environmental impacts of international food 
trade by taking multi-metrics into consideration (Dalin and RodriguezIturbe, 2016; MacDonald et al., 2015).

The intensification scenario included the effects of intensification in irrigation and $\mathrm{N}$ inputs and avoidance of $\mathrm{N}$ over-application. Crop yields and consumption in BWU and TWU would increase under the intensification scenario. Also, $\mathrm{N}$ uses would increase and more $\mathrm{N}$ would be lost to the environment in regions that under-applied $\mathrm{N}$ in the baseline. However, changes in water and $\mathrm{N}$ use intensities and $\mathrm{N}$ loss intensities between intensification and baseline were quite different for different countries, due to variable input intensification levels considered by the intensification scenario and different agro-climatic yield potentials (Mueller et al., 2012). Generally, water and $\mathrm{N}$ use intensities and $\mathrm{N}$ loss intensities would converge across countries in the intensification scenario compared to the baseline situation (Tables S3-S5). Combining the decreased export volumes in most food trade links (Fig. S1), agricultural input intensification according to the intensification scenario could largely reduce global water and $\mathrm{N}$ use conservation and reduction in $\mathrm{N}$ losses associated with food trade. Still, agricultural input intensification creates a more balanced world. It improves crop yields, reduces the need for import and enhances self-sufficiency and food security, particularly for the lowest performing countries in Africa (Sanchez, 2010). Besides, there is another positive outcome for the major exporting countries under the input intensification scenario, as they could reduce their own export-associated water and $\mathrm{N}$ consumption, as well as $\mathrm{N}$ losses.

The conserved water resources and reduced $\mathrm{N}$ pollution presented in this study indicate potential to tackle the issues related to resource depletion and environmental degradation. Particularly, detailed information regarding trade links, which saved the most blue water and reduced the most $\mathrm{N}$ losses, could be helpful for informing policies. For instance, food trade between the USA and Egypt not only conserved a large amount of blue water, but also reduced $\mathrm{N}$ losses, therefore, this trade partnership could be encouraged. The effects of food trade in conserving resources and reducing pollution are achieved by locating food production in better performance exporting countries and exporting to lower performance importing countries. These effects may differ when land use change is considered (MacDonald et al., 2015). For example, relocating food production to importing countries could entail some shifts from high resource uses to low resource uses crops. Therefore, the conserved resources and reduced pollution due to food trade may be offset if land use shifts are taken into account. However, considering the effects of land use change is out of the scope of study but should be the focus of future study.

We also recognized some limitations of this study. First, an important major crop, i.e. soybean, was excluded in the study. This was because that we focused on environmental pollution due to $\mathrm{N}$ fertilization, while soybean largely relies on biological $\mathrm{N}$ fixation. This exclusion has some effects on the trade pattern, especially for China as it imported a large amount of soybean (Dalin et al., 2015). Second, the baseline scenario was conducted for the situation of years around 2000, which was mainly constrained by the availability of current fertilizer data although the most up-to-date crop-specific fertilizer data were used. While more fertilizer has been applied to croplands (Liu et al., 2016c) and global food trade (Antonelli et al., 2017) has enlarged until recently, this study still provides insightful information regarding the implication of international food trade on global water resources, $\mathrm{N}$ fertilizer and $\mathrm{N}$ losses. Third, only one crop model was employed in this study. Uncertainties derived from model selection in yields and crop water estimation could be high (Rosenzweig et al., 2014). Besides, uncertainties associated with model algorithms and model parameters will also affect simulation results. Although previous studies showed that EPIC/PEPIC could provide robust estimation of crop water use, yields, and $\mathrm{N}$ losses (Balkovič et al., 2014; Folberth et al., 2012, 2014; Liu et al., 2016b, 2016c), a comprehensive demonstration of uncertainties related to multi-sources, e.g. multi-model, model structure and parameters should be considered in further research. Last but not least, to investigate the impact of agricultural intensification on crop trade, we used percentage increases in yields derived from improved $\mathrm{N}$ and irrigation management as a shocking factor to run the GTAP model. While there are other factors (e.g. population, policy, and technology) that can affect food trade (Dalin et al., 2015), only considering changes in yields is a common practice in using GTAP in order to reduce the complexity of the simulation (Konar et al., 2016). With this approach, we isolated the influence of increased $\mathrm{N}$ and irrigation inputs, particularly in countries with low inputs in the baseline, on global food trade by keeping other factors unchanged. Our main research objective was achieved. Including other factors, which may change trade picture, deserves more detailed research in the future.

\section{Conclusions}

In this study, we combined the EPIC/PEPIC model with the GTAP model to investigate the impacts of international trade of three major crops on water and $\mathrm{N}$ use and $\mathrm{N}$ losses in the baseline year 2000 and in an intensification scenario regarding increased $\mathrm{N}$ and irrigation inputs. We systematically demonstrated that global food trade did reduce $\mathrm{N}$ losses and conserve a large amount of $\mathrm{N}$ inputs and water resources. In particular, conservation in BWU through food trade accounted for more than half of the total BWU consumption for producing the three crops. This suggests that enlarging food trade could further improve these benefits. However, it brings challenges in enhancing selfsufficiency and food security for the lowest performing countries. Agricultural intensification improves crop yields and holds the key to address the challenges. As a result of the converging water use, $\mathrm{N}$ use and $\mathrm{N}$ loss intensities across countries, water and $\mathrm{N}$ use conservation and reduction in $\mathrm{N}$ losses associated with international food trade will decline under the intensification scenario. The study provides useful information to understand the implications of international food trade and agricultural intensification for resources use and pollution patterns.

\section{Acknowledgements}

This study was supported by funding from the Swiss Federal Institute of Aquatic Science and Technology (Eawag). W.L. acknowledges the support received from the Early Postdoctoral Mobility Fellowship awarded by Swiss National Science Foundation (P2EZP2_175096). Y.L. was supported by the National Key Research and Development Program of China (grant no. 2016YFA0602500) and the Major Program of National Natural Science Foundation of China (grant no. 91325302). M.K. was supported by Academy of Finland funded project WASCO (grant no. 305471), Emil Aaltonen Foundation funded project "eatless-water", and Academy of Finland SRC project "Winland". J.L. was supported by the National Science Fund for Distinguished Youth Scholars (grant no. 41625001) and the National Natural Science Foundation of China (grant no. 41571022).

\section{Appendix A. Supplementary data}

Supplementary data to this article can be found online at https://doi. org/10.1016/j.scitotenv.2018.03.306.

\section{References}

Antonelli, M., Tamea, S., 2015. Food-water security and virtual water trade in the Middle East and North Africa. Int. J. Water Resour. Dev. 31 (3), 326-342.

Antonelli, M., Tamea, S., Yang, H., 2017. Intra-EU agricultural trade, virtual water flows and policy implications. Sci. Total Environ. 587-588, 439-448.

Balkovič J van der Velde, M. Skalský, R Xiong W., Folberth, C. Khabarov, N. Smirnov, A., Mueller, N.D., Obersteiner, M., 2014. Global wheat production potentials and management flexibility under the representative concentration pathways. Glob. Planet. Chang. 122, 107-121.

Batjes, N.H., 2006. ISRIC-WISE Derived Soil Properties on a 5 by 5 Arc-minutes Global Grid (Version 1.1). ISRIC - World Soil Information, Wageningen.

Chapagain, A.K., Hoekstra, A.Y., Savenije, H.H.G., 2006. Water saving through international trade of agricultural products. Hydrol. Earth Syst. Sci. 10 (3), 455-468. 
Dalin, C., Rodriguez-Iturbe, I., 2016. Environmental impacts of food trade via resource use and greenhouse gas emissions. Environ. Res. Lett. 11 (3), 035012.

Dalin, C., Qiu, H., Hanasaki, N., Mauzerall, D.L., Rodriguez-Iturbe, I., 2015. Balancing water resource conservation and food security in China. Proc. Natl. Acad. Sci. U. S. A. 112 (15), 4588-4593.

Dalin, C., Wada, Y., Kastner, T., Puma, M.J., 2017. Groundwater depletion embedded in international food trade. Nature 543 (7647), 700-704.

DeFries, R.S., Rudel, T., Uriarte, M., Hansen, M., 2010. Deforestation driven by urban population growth and agricultural trade in the twenty-first century. Nat. Geosci. 3 (3), $178-181$.

D'Odorico, P., Carr, J.A., Laio, F., Ridolfi, L., Vandoni, S., 2014. Feeding humanity through global food trade. Earth's Future 2 (9), 458-469.

Elliott, J., Muller, C., Deryng, D., Chryssanthacopoulos, J., Boote, K.J., Buchner, M., Foster, I., Glotter, M., Heinke, J., Iizumi, T., Izaurralde, R.C., Mueller, N.D., Ray, D.K., Rosenzweig, C., Ruane, A.C., Sheffield, J., 2015. The Global Gridded Crop Model Intercomparison: data and modeling protocols for phase 1 (v1.0). Geosci. Model Dev. 8 (2), 261-277.

Ercin, A.E., Hoekstra, A.Y., 2014. Water footprint scenarios for 2050: a global analysis. Environ. Int. 64, 71-82.

Fader, M., Gerten, D., Thammer, M., Heinke, J., Lotze-Campen, H., Lucht, W., Cramer, W., 2011. Internal and external green-blue agricultural water footprints of nations, and related water and land savings through trade. Hydrol. Earth Syst. Sci. 15 (5), 1641-1660.

Feng, K.S., Hubacek, K., Pfister, S., Yu, Y., Sun, L.X., 2014. Virtual scarce water in China. Environ. Sci. Technol. 48 (14), 7704-7713.

Folberth, C., Gaiser, T., Abbaspour, K.C., Schulin, R., Yang, H., 2012. Regionalization of a large-scale crop growth model for sub-Saharan Africa: model setup, evaluation, and estimation of maize yields. Agric. Ecosyst. Environ. 151, 21-33.

Folberth, C., Yang, H., Gaiser, T., Liu, J., Wang, X., Williams, J., Schulin, R., 2014. Effects of ecological and conventional agricultural intensification practices on maize yields in sub-Saharan Africa under potential climate change. Environ. Res. Lett. 9 (4), 044004

Folberth, C., Skalsky, R., Moltchanova, E., Balkovic, J., Azevedo, L.B., Obersteiner, M., van der Velde, M., 2016. Uncertainty in soil data can outweigh climate impact signals in global crop yield simulations. Nat. Commun. 7, 11872.

Gassman, P.W., Williams, J.R., Benson, V.W., Izaurralde, R.C., Hauck, L.M., Jones, C.A., Atwood, J.D., Kiniry, J.R., Flowers, J.D., 2005. Historical Development and Applications of the EPIC and APEX Models. Iowa State University, Center for Agricultural and Rural Development, Ames, Iowa (Working Paper 05-WP 397).

Gu, Z., 2014. Circlize implements and enhances circular visualization in R. Bioinformatics https://doi.org/10.1093/bioinformatics/btu393.

Hanasaki, N., Inuzuka, T., Kanae, S., Oki, T., 2010. An estimation of global virtual water flow and sources of water withdrawal for major crops and livestock products using a global hydrological model. J. Hydrol. 384 (3-4), 232-244.

Hertel, T.W., 1997. Global Trade Analysis: Modeling and Applications. Cambridge University Press.

Hoekstra, A.Y., 2017. Water footprint assessment: evolvement of a new research field. Water Resour. Manag. 31 (10), 3061-3081.

Hoekstra, A.Y., Hung, P.Q., 2005. Globalisation of water resources: international virtual water flows in relation to crop trade. Glob. Environ. Chang. 15 (1), 45-56.

Hoekstra, A.Y., Mekonnen, M.M., 2012. The water footprint of humanity. Proc. Natl. Acad. Sci. U. S. A. 109 (9), 3232-3237.

Izaurralde, R.C., Williams, J.R., McGill, W.B., Rosenberg, N.J., Jakas, M.C.Q., 2006. Simulating soil C dynamics with EPIC: model description and testing against long-term data. Ecol. Model. 192 (3-4), 362-384.

Kastner, T., Erb, K.H., Haberl, H., 2014. Rapid growth in agricultural trade: effects on global area efficiency and the role of management. Environ. Res. Lett. 9 (3), 034015.

Konar, M., Hussein, Z., Hanasaki, N., Mauzerall, D.L., Rodriguez-Iturbe, I., 2013. Virtual water trade flows and savings under climate change. Hydrol. Earth Syst. Sci. 17 (8), 3219-3234.

Konar, M., Reimer, J.J., Hussein, Z., Hanasaki, N., 2016. The water footprint of staple crop trade under climate and policy scenarios. Environ. Res. Lett. 11 (3), 035006.

Lassaletta, L., Billen, G., Garnier, J., Bouwman, L., Velazquez, E., Mueller, N.D., Gerber, J.S., 2016. Nitrogen use in the global food system: past trends and future trajectories of agronomic performance, pollution, trade, and dietary demand. Environ. Res. Lett. 11 (9), 095007.

Liu, J., Zehnder, A.J.B., Yang, H., 2009. Global consumptive water use for crop production: the importance of green water and virtual water. Water Resour. Res. 45 (5), W05428.

Liu, J., Hertel, T.W., Taheripour, F., Zhu, T.J., Ringler, C., 2014. International trade buffers the impact of future irrigation shortfalls. Glob. Environ. Chang. 29, 22-31.

Liu, J., Ma, K., Ciais, P., Polasky, S., 2016a. Reducing human nitrogen use for food production. Sci. Rep. 6, 30104.

Liu, W., Yang, H., Folberth, C., Wang, X., Luo, Q., Schulin, R., 2016b. Global investigation of impacts of PET methods on simulating crop-water relations for maize. Agric. For. Meteorol. 221, 164-175.

Liu, W., Yang, H., Liu, J., Azevedo, L.B., Wang, X., Xu, Z., Abbaspour, K.C., Schulin, R., 2016c. Global assessment of nitrogen losses and trade-offs with yields from major crop cultivations. Sci. Total Environ. 572, 526-537.

Liu, W., Antonelli, M., Liu, X., Yang, H., 2017. Towards improvement of grey water footprint assessment: with an illustration for global maize cultivation. J. Clean. Prod. $147,1-9$.

Lun, F., Liu, J., Ciais, P., Nesme, T., Chang, T., Wang, R., Goll, D., Sardans, J., Peñuelas, J., Obersteiner, M., 2018. Global and regional phosphorus budgets in agricultural systems and their implications for phosphorus-use efficiency. Earth Syst. Sci. Data 10, $1-18$.
MacDonald, G.K., Bennett, E.M., Carpenter, S.R., 2012. Embodied phosphorus and the global connections of United States agriculture. Environ. Res. Lett. 7 (4), 044024.

MacDonald, G.K., Brauman, K.A., Sun, S.P., Carlson, K.M., Cassidy, E.S., Gerber, J.S., West P.C., 2015. Rethinking agricultural trade relationships in an era of globalization. Bioscience 65 (3), 275-289.

Marston, L., Konar, M., Cai, X.M., Troy, T.J., 2015. Virtual groundwater transfers from overexploited aquifers in the United States. Proc. Natl. Acad. Sci. U. S. A. 112 (28), 8561-8566.

Martinez-Melendez, L.A., Bennett, E.M., 2016. Trade in the US and Mexico helps reduce environmental costs of agriculture. Environ. Res. Lett. 11 (5), 055004.

Mueller, N.D., Gerber, J.S., Johnston, M., Ray, D.K., Ramankutty, N., Foley, J.A., 2012. Closing yield gaps through nutrient and water management. Nature 490 (7419), 254-257.

Müller, C., Elliott, J., Chryssanthacopoulos, J., Arneth, A., Balkovic, J., Ciais, P., Deryng, D. Folberth, C., Glotter, M., Hoek, S., Iizumi, T., Izaurralde, R.C., Jones, C., Khabarov, N., Lawrence, P., Liu, W., Olin, S., Pugh, T.A.M., Ray, D.K., Reddy, A., Rosenzweig, C., Ruane, A.C., Sakurai, G., Schmid, E., Skalsky, R., Song, C.X., Wang, X., de Wit, A., Yang, H., 2017. Global gridded crop model evaluation: benchmarking, skills, deficiencies and implications. Geosci. Model Dev. 10 (4), 1403-1422.

Nesme, T., Roques, S., Metson, G.S., Bennett, E.M., 2016. The surprisingly small but increasing role of international agricultural trade on the European Union's dependence on mineral phosphorus fertiliser. Environ. Res. Lett. 11 (2), 025003.

O'Bannon, C., Carr, J., Seekell, D.A., D'Odorico, P., 2014. Globalization of agricultural pollution due to international trade. Hydrol. Earth Syst. Sci. 18 (2), 503-510.

Oita, A., Malik, A., Kanemoto, K., Geschke, A., Nishijima, S., Lenzen, M., 2016. Substantia nitrogen pollution embedded in international trade. Nat. Geosci. 9 (2), 111-115.

Oki, T., Kanae, S., 2004. Virtual water trade and world water resources. Water Sci. Technol. 49 (7), 203-209.

Parton, W.J., Schimel, D., Ojima, D., Cole, C.V., Bryant, R., Arnold, R., 1994. A general model for soil organic matter dynamics: sensitivity to litter chemistry, texture and management. Quantitative Modeling of Soil Forming Processes: Proceedings of a Symposium Sponsored by Divisions S-5 and S- 9 of the Soil Science Society of America in Minneapolis, Minnesota, USA, 2 Nov. 1992. Soil Science Society of America Inc., pp. 147-167.

Porkka, M., Kummu, M., Siebert, S., Varis, O., 2013. From food insufficiency towards trade dependency: a historical analysis of global food availability. PLoS One 8 (12), e82714

Porkka, M., Guillaume, J.H.A., Siebert, S., Schaphoff, S., Kummu, M., 2017. The use of food imports to overcome local limits to growth. Earth's Future 5, 393-407.

Portmann, F.T., Siebert, S., Doll, P., 2010. MIRCA2000-global monthly irrigated and rainfed crop areas around the year 2000: a new high-resolution data set for agricultural and hydrological modeling. Glob. Biogeochem. Cycles 24, GB1011.

Porwollik, V., Müller, C., Elliott, J., Chryssanthacopoulos, J., Iizumi, T., Ray, D.K., Ruane, A.C., Arneth, A., Balkovič, J., Ciais, P., Deryng, D., Folberth, C., Izaurralde, R.C., Jones, C.D. Khabarov, N., Lawrence, P.J., Liu, W., Pugh, T.A.M., Reddy, A., Sakurai, G., Schmid, E. Wang, X., de Wit, A., Wu, X., 2017. Spatial and temporal uncertainty of crop yield aggregations. Eur. J. Agron. 88, 10-21.

Rosenzweig, C., Jones, J.W., Hatfield, J.L., Ruane, A.C., Boote, K.J., Thorburn, P., Antle, J.M. Nelson, G.C., Porter, C., Janssen, S., Asseng S., Basso, B., Ewert, F. Wallach, D. Baigorria, G., Winter, J.M., 2013. The Agricultural Model Intercomparison and Improvement Project (AgMIP): protocols and pilot studies. Agric. For. Meteorol. 170 $166-182$.

Rosenzweig, C., Elliott, J., Deryng, D., Ruane, A.C., Muller, C., Arneth, A., Boote, K.J., Folberth, C., Glotter, M., Khabarov, N., Neumann, K., Piontek, F., Pugh, T.A.M., Schmid, E. Stehfest, E., Yang, H., Jones, J.W., 2014. Assessing agricultural risks of climate change in the 21st century in a global gridded crop model intercomparison. Proc. Natl. Acad. Sci. U. S. A. 111 (9), 3268-3273.

Sacks, W.J., Deryng, D., Foley, J.A., Ramankutty, N., 2010. Crop planting dates: an analysis of global patterns. Glob. Ecol. Biogeogr. 19 (5), 607-620.

Sanchez, P.A., 2010. Tripling crop yields in tropical Africa. Nat. Geosci. 3 (5), 299-300.

Smil, V., 1999. Nitrogen in crop production: an account of global flows. Glob. Biogeochem. Cycles 13 (2), 647-662.

Sutton, M.A., Bleeker, A., Howard, C.M., Bekunda, M., Grizzetti, B., de Vries, W., van Grinsven, H.J.M., Abrol, Y.P., Adhya, T.K., Billen, G., Davidson, E.A., Datta, A., Diaz, R. Erisman, J.W., Liu, X.J., Oenema, O., Palm, C., Raghuram, N., Reis, S., Scholz, R.W., Sims, T., Westhoek, H., Zhang, F.S., 2013. Our Nutrient World: The Challenge to Produce More Food and Energy With Less Pollution. Centre for Ecology and Hydrology (CEH).

Wang, R.R., Zimmerman, J., 2016. Hybrid analysis of blue water consumption and water scarcity implications at the global, national, and basin levels in an increasingly globalized world. Environ. Sci. Technol. 50 (10), 5143-5153.

Weedon, G.P., Balsamo, G., Bellouin, N., Gomes, S., Best, M.J., Viterbo, P., 2014. The WFDEI meteorological forcing data set: WATCH forcing data methodology applied to ERAinterim reanalysis data. Water Resour. Res. 50 (9), 7505-7514.

West, P.C., Gerber, J.S., Engstrom, P.M., Mueller, N.D., Brauman, K.A., Carlson, K.M., Cassidy, E.S., Johnston, M., MacDonald, G.K., Ray, D.K., Siebert, S., 2014. Leverage points for improving global food security and the environment. Science 345 (6194), 325-328

Williams, J.R., 1995. The EPIC model. In: Singh, V.P. (Ed.), Computer Models of Watershed Hydrology. Water Resources Publications, Highlands Ranch, Colo.

Williams, J.R., Jones, C.A., Dyke, P.T., 1984. A modeling approach to determining the relationship between erosion and soil productivity. Trans. ASAE 27 (1), 129-144.

Yang, H., Wang, L., Abbaspour, K.C., Zehnder, A.J.B., 2006. Virtual water trade: an assessment of water use efficiency in the international food trade. Hydrol. Earth Syst. Sci. 10 (3), 443-454.

Yang, H., Pfister, S., Bhaduri, A., 2013. Accounting for a scarce resource: virtual water and water footprint in the global water system. Curr. Opin. Environ. Sustain. 5 (6), 599-606. 
Zhang, Z.Y., Shi, M.J., Yang, H., 2012. Understanding Beijing's water challenge: a decomposition analysis of changes in Beijing's water footprint between 1997 and 2007. Environ. Sci. Technol. 46 (22), 12373-12380.

Zhang, Q., Jiang, X., Tong, D., Davis, S.J., Zhao, H., Geng, G., Feng, T., Zheng, B., Lu, Z., Streets, D.G., Ni, R., Brauer, M., van Donkelaar, A., Martin, R.V., Huo, H., Liu, Z., Pan, D., Kan, H. Yan, Y., Lin, J., He, K., Guan, D., 2017. Transboundary health impacts of transported global air pollution and international trade. Nature 543 (7647), 705-709.

Zhao, X., Liu, J.G. Liu, QY, Tillotson, M.R., Guan, D.B., Hubacek, K., 2015. Physical and virtual water transfers for regional water stress alleviation in China. Proc. Natl. Acad. Sci. U. S. A. 112 (4), 1031-1035.
Zhao, X., Liu, J., Yang, H., Duarte, R., Tillotson, M.R., Hubacek, K., 2016. Burden shifting of water quantity and quality stress from megacity Shanghai. Water Resour. Res. 52 (9), 6916-6927.

Zhu, A.N., Zhang, J.B., Zhao, B.Z., Cheng, Z.H., Li, L.P., 2005. Water balance and nitrate leaching losses under intensive crop production with Ochric Aquic Cambosols in North China Plain. Environ. Int. 31 (6), 904-912.

Zhuo, L., Mekonnen, M.M., Hoekstra, A.Y., 2016. Consumptive water footprint and virtual water trade scenarios for China - with a focus on crop production, consumption and trade. Environ. Int. 94, 211-223. 